\title{
LATE HOLOCENE PALAEOENVIRONMENT OF TSE DURA, A LATER STONE AGE (LSA) ROCK SHELTER, NORTH-CENTRAL NIGERIA
}

\author{
Emuobosa Akpo Orijemie \\ McDonald Institute for Archaeological Research, University of Cambridge, United Kingdom and Department of Archaeo- \\ logy and Anthropology, University of Ibadan, Nigeria, e-mail: orijemie5@yahoo.com
}

\begin{abstract}
Palynological and archaeobotanical analyses were conducted on excavated sediments from Tse Dura, a Later Stone Age rock shelter in north-central Nigeria with the aim of reconstructing the environment conditions at the site within the last millennium. From $933 \pm 29$ BP to $802 \pm 29$ BP, the environment alternated between Guinea savanna with dry conditions, and secondary and riverine forests with humid conditions. During these periods of environmental fluctuations, the LSA populations engaged in the management of economic plants the most significant of which included Dioscorea spp. Pennisetum glaucum and Elaeis guineensis, and exploited wild plants such as Pavetta crassipes, Sarcocephalus latifolius and Lophira cf. lanceolata for dietary and ethnomedicinal purposes. Around $310 \pm 30 \mathrm{BP}$ cal, the environment became very wet after which it was succeeded by a drier period. It was during this period that Sorghum bicolor became prominent, and the environment attained its current status dominated by Guinea savanna elements and secondary forests.
\end{abstract}

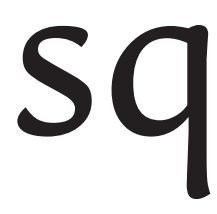

Key words: Microliths, Vegetation history, Plant management, Tiv, Middle Benue Valley, Nigeria.

Manuscript received 24 September 2017, accepted 5 May 2018

\section{INTRODUCTION}

The environment has been recognised as a significant factor which influences the cultural evolution of humans. Some of the major defining moments in human history have been linked to, directly or otherwise, or accompany environmental change. One of such recent changes occurred during the Later Stone Age (LSA) when the use of microliths replaced heavy core tools; this period is recognised in Nigeria to have begun around ca. 12,000 BP (Shaw and Daniels, 1984). Majority of dates surrounding the occupation period of LSA rock shelter sites in Nigeria cluster around 2,000 BP giving the impression that the LSA ended around that time or was succeeded by Iron Age groups shortly after. However, there is evidence that LSA populations lasted until ca. 1,000 BP in Kariya Wuro (Allsworth-Jones, 2015). An attempt was made to use palynology to reconstruct the palaeoenvironment during the cultural change at Iwo Eleru but the sediments proved too oxidised hence no pollen grains were preserved. However, the change in lithics was linked to environmental (vegetation) change (Shaw and Daniels, 1984). It was inferred that microliths were adapted for hunting when the vegetation changed from a forest to savanna and similar open vegetations. This interpretation was based on palaeobotanical records obtained from other areas in the West African sub-re- gion such as those of Kintampo and Bosumpra in Ghana, which lie in the same forest zone, have similar archaeological finds and were occupied at about the same time. Although, the inference is plausible it has not been established. Compared to the number of LSA rock shelters investigated in Nigeria so far (Soper, 1965; York, 1978; Andah, 1983; Fatunsin, 1996; Alabi et al., 2009; Allsworth-Jones et al., 2012), very few, namely Kariya Wuro (Sowunmi and Awosina, 1991) and Abeokuta (Orijemie et al., in press) have been directly studied with palaeoenvironmental interest. The general idea, which is not significantly different from the interpretation at Iwo Eleru, is that microliths were developed for hunting in the savanna or at least in an open environment. This view has recently been questioned by Alabi (2016) who argued, based on the recovery of microliths from rock shelters sites in the rainforest zone, that they could have been used in both environments.

In the north-central part of Nigeria, the vegetation of which is Guinea savanna and forest-savanna ecotones with pockets of drier forest type, and gallery forests, some rock shelters have been investigated (Allsworth-Jones et al., 2012) but the palaeoenvironmental conditions under which they were occupied are uncertain. At Itaakpa rock shelter in Kogi State, north-central Nigeria where microliths were recovered in abundance (Allsworth-Jones et al., 2012), pollen from an $80 \mathrm{~cm}$ sediment-core of a pond near 


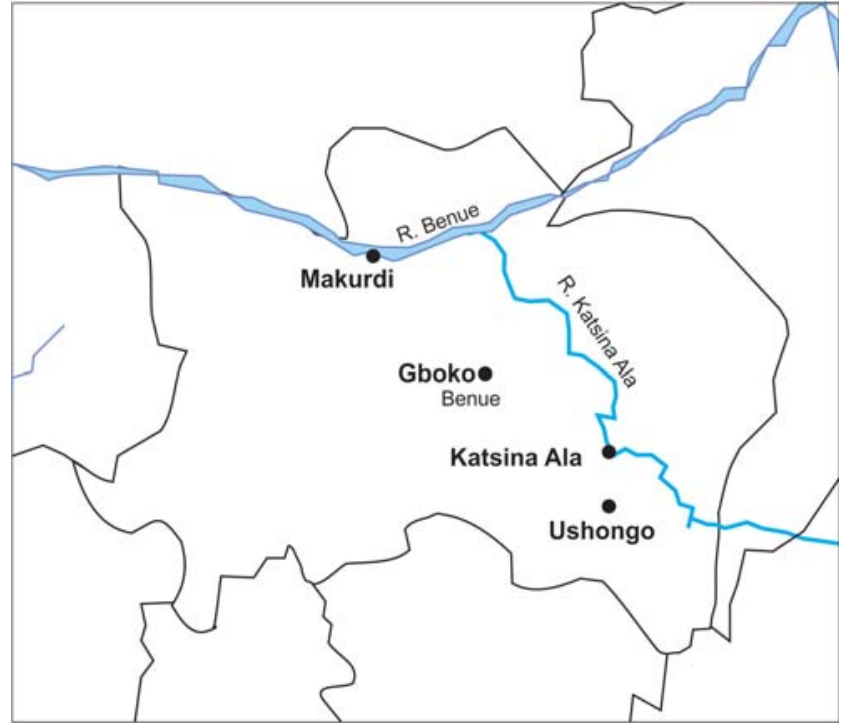

Fig. 1. Map of the study area showing Tse Dura and other localities in the Middle Benue Valley.

the rock shelter indicated a marked decrease in forest elements (at the earliest period) to that of open vegetation dominated by Elaeis guineensis and herbaceous elements in the upper levels (Oyelaran, 2002). Unfortunately, the sequence was undated hence its relationship with the occupation of the rock shelter remains hazy. At Tse Dura rock shelter site, north-central Nigeria, the subject of this paper, the earliest occupants (before 2,330 BP) used pottery decorated mainly with string roulette; other decoration patterns were grooves, incisions and comb-stamping. Subsequently, after ca. 2,000 BP, pottery with knitted mat impression appeared; other decoration types occurred but the latter remained dominant throughout. This indicated the arrival of a new population in the region (Andah, 1983). Sedimentological and mineralogical analyses of sediments from the Tse Dura rock shelters, and floodplains of the Rivers Katsina Ala, Tete and Ojapo (Cross River basin) revealed three climatic phases in the area, namely (a) an early very wet and warm phase assigned to a time shortly before 2,330 BP., (b) a middle wet and warm phase of 1,100 $\pm 80 \mathrm{BP}$ and (c) a later dry and cool phase assigned to post 1,100 BP (Tubosun, 1981, 1995; Tubosun and Andah, 1983). However, the vegetation history was not investigated. This paper discusses the palaeoenvironmental conditions surrounding the occupation of the LSA archaeological site of Tse Dura KA 4 in Ushongo, Benue State, north-central Nigeria in the light of recent environmental archaeological investigations in the site.

\section{REGIONAL SETTING}

The Tse Dura KA 4 rock shelters, RS 1 and RS 2 are located on a hill by the same name near Ushongo village in Benue State, north central Nigeria (Fig. 1). They were first excavated from 1975 to 1983 (Andah, 1983). The rock shelter, KA4 RS 1 (N0656’08.38”, E009¹5'49.24”), is located on a lower ridge (ca. $298 \mathrm{~m}$ above sea level) on the south west of the hill complex while the second rock shelter, K4 RS 2 is on a higher ridge ( $c$ a. $306 \mathrm{~m}$ asl) at the southeast of the major ridge hill complex. The hill complex is made up of granitic rock; the vegetation on the hill is characterised by grasses dominated by Pennisetum sp., Andropogon sp.; trees and shrubs included Alchornea sp., Bridelia ferruginea, Daniellia oliveri, Dracaena arborea, Hymenocardia acida, Prosopis africana, Isoberlinia spp., Ficus spp., and Lophira lanceolata; weeds include Aspilia africana, Chromolaena odorata, Tridax procumbens, Sida acuta; protected plants include Elaeis guineensis, Parkia biglobosa, Tectonia grandis and Bombax costatum, Most areas on the hill slops and plains have been heavily cultivated with Dioscorea spp., Manihot esculenta, Arachis hypogea, Sorghum bicolor, Zea mays, Mangifera indica and Citrus spp. Several river channels which run near the Tse Dura hill complex were more active in the past than now. Two of which are Rivers Dura and Amire Tamen; both are tributaries of the Katsina Ala River.

\section{MATERIALS AND METHODS}

After extensive discussions with some members of the 1975-1983 excavation team and consulting the 1983 excavation reports (Andah, 1983; Tubosun and Andah, 1983), a $2 \times 2 \mathrm{~m}$ (B1) and another $2 \times 1 \mathrm{~m}$ (B2) trenches were sunk in undisturbed deposits in Chamber 1 of RS 1 at the southernmost narrow end of the rock shelter. This report is based on the $2 \times 2 \mathrm{~m}$ trench (B 1). Excavation followed $10 \mathrm{~cm}$ spit levels and came to an end at a sterile layer of depth $110 \mathrm{~cm}$ below the surface (Fig. 2). Sediment samples for pollen analysis were collected from the eastern wall of the trench at $5 \mathrm{~cm}$ intervals; the eastern wall was the most intact (Fig. 2). However, this wall was a bit slant such that $0-20 \mathrm{~cm}$ of the $110 \mathrm{~cm}$ deposit was not present. Nineteen samples were collected representing $20-110 \mathrm{~cm}$ of the B1 trench; Soil colour and texture were noted using Munsell Soil Colour and soil particle size/class charts (Table 1). Five grams from each sample was subjected to standard pollen analysis procedure (Faegri and Iversen, 1988) but without acetolysis because of the presumed fragile nature of the palynomorphs. Afterwards, the final residue recov-

Table 1. Lithology of sediment samples from trench B1, Tse Dura RS 1.

\begin{tabular}{|c|c|c|c|}
\hline \multirow{2}{*}{$\begin{array}{c}\text { Depth } \\
\text { (cm) }\end{array}$} & \multirow{2}{*}{$\begin{array}{c}\text { Stratigraphic } \\
\text { Units }\end{array}$} & \multicolumn{2}{|c|}{ Soil } \\
\cline { 3 - 4 } & colour & texture \\
\hline $20-35$ & A & dark grey & loose/sandy \\
\hline $35-55$ & B & brown & gritty/sandy \\
\hline $55-70$ & C & light brown & semi-compact/clay \\
\hline $70-95$ & D & yellowish brown & gritty/sandy \\
\hline $95-110$ & F & red & compact/clay \\
\hline
\end{tabular}




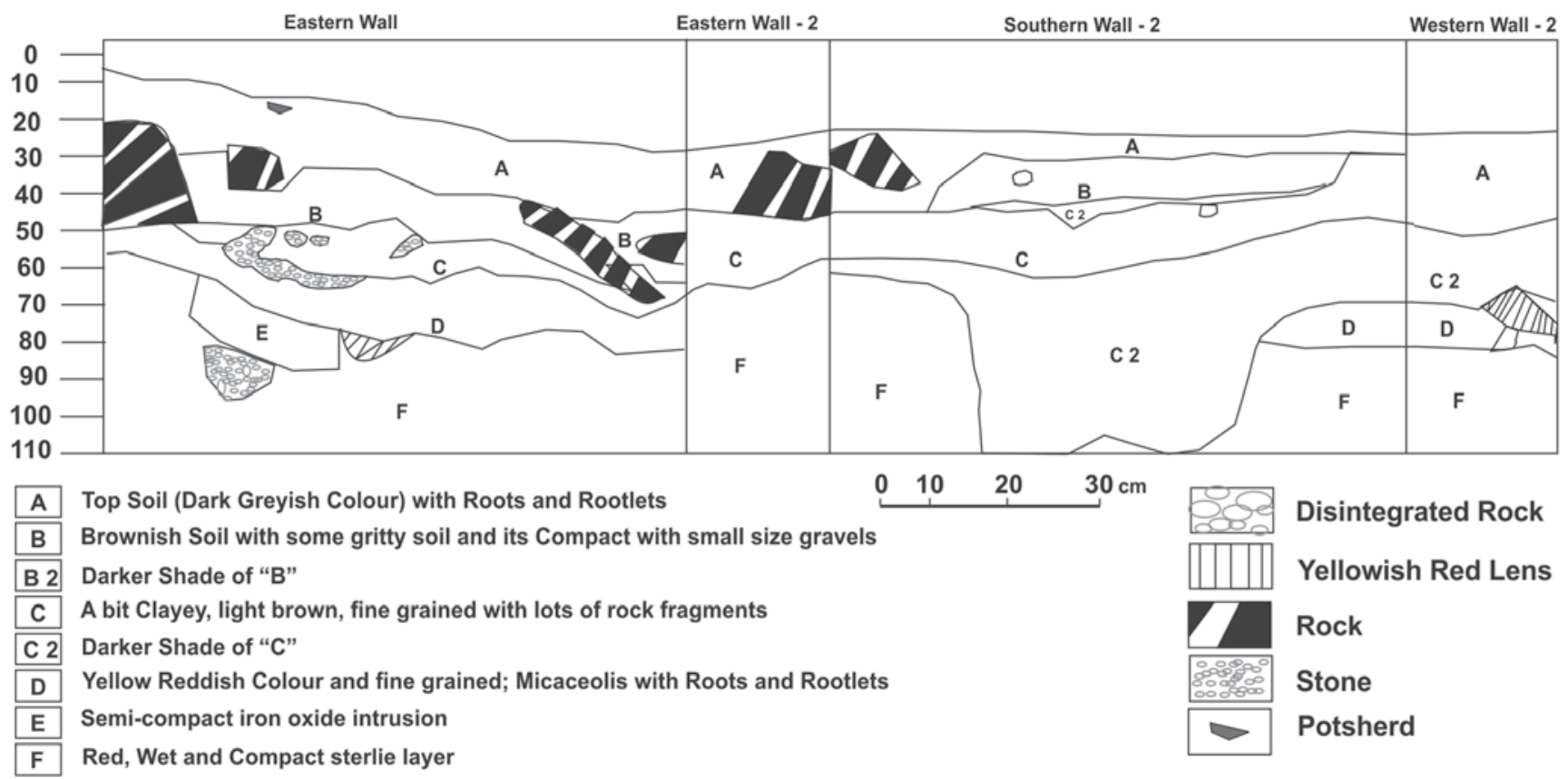

Fig. 2. Stratigraphic profiles of Square B 1, Tse Dura KA4 RS 1.

ered came to $2 \mathrm{ml}$; a micropipette was used to draw $10 \mu \mathrm{l}$ from the residue onto duplicate slides; $10 \mu \mathrm{l}$ was mounted on each slide. The slides were studied under $\times 40$ and $\times 100$ objectives of an Olympus Light Microscope. All palynomorphs including pollen, spores (pteridophytes and fungi) and algae were counted. However, fungal spores, algae and phytoliths were not included in the pollen sum but their occurrence was expressed as percentages of the total number of palynomorphs recovered. As much as possible, palynomorphs were classified into phytoecological groups based on the natural habitats of their identified parent plants (Keay, 1959; Hutchinson and Dalziel, 1958-1972) and/or hosts in the case of fungi (Argant et al., 2006; Barboni et al., 2007; van Geel et al., 2011).

Pollen diagrams were produced with TILIA software; those of pollen and pteridophyte spores were plotted separately from those of fungal spores, algae and phytoliths. To have a better understanding of the past climate of the site, a comparison was made between taxa known to be natural to wet and dry environments. In addition, soil samples from all the levels of the excavated trench were floated and screened through $1 \mathrm{~mm}$ and $300 \mu \mathrm{m}$ set of sieves for seeds, fruits and charcoal, the main results of which are presented elsewhere (Orijemie, in press) but shall be highlighted here.
Charcoal samples recovered during the excavation from the trench were sent to SUERC Radiocarbon Laboratory, Glasgow for AMS dating (Table 2). The date ranges were calibrated using the IntCal13 atmospheric calibration curve (Reimer et al., 2013). Presented in Tables 3 and 4 are the archaeological finds materials recovered from the excavation and constituent palynomorphs of the phytoecological groups respectively.

\section{RESULTS}

\section{Lithologic context of B1 Tse Dura rock shelter 1 (Fig. 2)}

Layer A is the top soil; it is a sandy deposit, dark grey in colour and approximately $15-35 \mathrm{~cm}$ thick. Layer B is a brown, gritty sandy soil that is approximately $10-20 \mathrm{~cm}$ thick; in the southern wall, a slightly different layer, B2 occurs within layer B; it is ca. $15 \mathrm{~cm}$ thick. Layer C is a light brown clayey soil that is about $5-15 \mathrm{~cm}$ thick. In the eastern wall directly below layer $\mathrm{C}$ is a slightly similar layer (i.e. in terms of colour and texture) $\mathrm{C} 2$, although it is darker due to lots of charred materials and charcoal contained therein. It is $c a .50 \mathrm{~cm}$ thick and was initially $c a .45 \mathrm{~cm}$ wide but

Table 2. Radiocarbon dates from Benue Valley, north-central Nigeria.

\begin{tabular}{|c|c|c|c|c|}
\hline Sample & Source & Depth $(\mathrm{cm})$ & C14 Age & 2 Sigma Cal (95\% Probability) \\
\hline Beta 444814 & Sediment core & 55 & $310 \pm 30 \mathrm{BP}$ & cal AD 1485-1650 \\
\hline SUERC-73889 & Tse Dura RS1 & $60-70$ & $802 \pm 29 \mathrm{BP}$ & cal AD 1274 \\
\hline SUERC-73890 & Tse Dura RS1 & $100-110$ & $933 \pm 29 \mathrm{BP}$ & cal AD 1161 \\
\hline
\end{tabular}


Table 3. Summary of materials recovered from KA4 RS 1 B1.

\begin{tabular}{|l|c|c|c|c|c|c|c|c|c|c|c|c|c|}
\hline Artefacts/Level (cm) & Surface & $0-10$ & $10-20$ & $20-30$ & $30-40$ & $40-50$ & $50-60$ & $60-70$ & $70-80$ & $80-90$ & $90-100$ & $100-110$ & Total \\
\hline Pottery & 228 & 103 & 180 & 638 & 1009 & 429 & 115 & 48 & 133 & 16 & 27 & 16 & 2942 \\
\hline Animal bones & 1 & - & - & 2 & 11 & 1 & - & - & - & - & - & - & 15 \\
\hline Animal teeth & - & - & - & 1 & - & 1 & - & - & 1 & - & - & - & 3 \\
\hline Bone tool (tanged) & - & - & - & 1 & - & - & - & - & - & - & - & - & 1 \\
\hline Charcoal & - & - & - & + & + & ++ & +++ & ++ & ++ & + & + & + & +++ \\
\hline Charred Wood & - & 6 & - & - & - & - & - & - & 1 & - & - & - & 7 \\
\hline Groundnut & 7 & 1 & - & - & - & - & - & - & - & - & - & - & 8 \\
\hline Unidentified seed & 1 & - & - & - & - & - & - & - & - & - & - & - & 1 \\
\hline Oil palm kernel & 9 & 21 & 3 & - & - & - & - & - & - & - & - & - & 33 \\
\hline Iron Slag & - & 240 & - & 45 & 7 & 4 & 11 & 6 & 7 & 2 & 4 & - & 326 \\
\hline Lithics & 2 & - & - & 53 & 223 & 60 & 151 & 51 & 72 & - & 4 & 1 & 617 \\
\hline Total & 248 & 371 & 183 & 740 & 1250 & 495 & 277 & 105 & 214 & 18 & 35 & 17 & 3953 \\
\hline
\end{tabular}

Table 4. Palynomorphs of the phytoecological groups/ hosts recovered from sediment samples of B1 Tse Dura RS1.

\begin{tabular}{|c|c|c|}
\hline \multicolumn{2}{|c|}{ Phytoecological groups/ hosts } & Taxa \\
\hline \multicolumn{2}{|c|}{ Freshwater/aquatics } & Cyperaceae, Lemna sp., Liliaceae, Nymphaea lotus, Typha australis \\
\hline \multicolumn{2}{|c|}{ Freshwater swamp forest } & $\begin{array}{c}\text { Allophylus africanus, Alstonia boonei, cf. Ancistrophyllum secondiflorum, Pterocarpus } \\
\text { santalinoides, Uapaca acuminata }\end{array}$ \\
\hline \multicolumn{2}{|l|}{ Dry forests } & $\begin{array}{l}\text { Antiaris sp., Bosquiea angolense, Ceiba pentandra, Centroplacus glacinus, Celtis/Ficus sp., } \\
\text { Diospyros sp., Entada gigas, Piptadeniastrum africanum, Irvingia gabonensis }\end{array}$ \\
\hline \multicolumn{2}{|c|}{ Secondary forest } & $\begin{array}{c}\text { Alchornea cf. cordifolia, Elaeis guineensis, Lecaniodiscus sp., Macaranga sp., Pycnanthus } \\
\text { angolensis }\end{array}$ \\
\hline \multicolumn{2}{|l|}{ Montane forest } & Anthocleista djalonensis, Ericaceae, Justicia flava, Podocarpus milanjianus, Myrica arborea \\
\hline \multicolumn{2}{|l|}{ Guinea savanna } & $\begin{array}{c}\text { Berlinia cf. grandiflora, Bombax costatum Borassus/Hyphaene, Bridelia cf. ferruginea, } \\
\text { Bridelia cf. micrantha, Canarium schweinfurthii type, Cissampelos mucronata, Hymenocardia } \\
\text { acida, Lannea cf. microcarpa, Lophira cf. lanceolata, Hymenocardia acida, Pavetta cf. } \\
\text { crassipes, Pericopsis angolensis, Prosopis africana, Parinari cf. kerstingii, Pterocarpus } \\
\text { erinaceus, Milletia cf. oblata, Nauclea latifolia, Parkia biglobosa, Senna hirsuta, Syzygium } \\
\text { guineense, Trema sp., Xyris sp. }\end{array}$ \\
\hline \multicolumn{2}{|l|}{ Cultivars } & $\begin{array}{c}\text { Citrus spp., Corchorus olitorius, Dioscorea spp., Mangifera indica, Manihot cf. esculentus, } \\
\text { Ocimum gratissimum, Sesamum cf. indicum, Vigna sp. }\end{array}$ \\
\hline \multicolumn{2}{|c|}{ Open vegetation } & $\begin{array}{l}\text { Alternanthera cf. repens, Amaranthaceae/Chenopodiaceae, Asteraceae, Asystasia gangetica, } \\
\text { Celosia sp., Celosia cf. argentea, Crassocephalum, Phyllanthus amarus, Poaceae }\end{array}$ \\
\hline \multirow[t]{2}{*}{ Ferns } & Triletes & $\begin{array}{l}\text { Cyathea sp., Congulisporites ornatus, Lycopodium cernuum, Ophioglossum sp., Pteris sp., } \\
\text { Selaginella sp. }\end{array}$ \\
\hline & Monoletes & Cyclosorus sp., monolete spores, Polypodium vulgare \\
\hline \multirow{5}{*}{$\begin{array}{l}\text { Fungi } \\
\text { (commensals) }\end{array}$} & Soil and dung & $\begin{array}{l}\text { Arnium sp., Brachydesmiella sp., Caryospora sp., Cercophora sp., Podospora sp., Sordaria sp., } \\
\text { Sporormiella sp. }\end{array}$ \\
\hline & Local fire and erosion & Chaetomium sp., Diporotheca sp., Glomus sp., Venturia sp. \\
\hline & Domesticated animals & Coniochaeta cf. ligniaria, Lasiodiplodia theobromae, Picaria sp., Podospora sp. \\
\hline & Cultigens & Alternaria cf. tenuissima, Aspergillus cf. flavus, Fusarium sp., Curvularia sp. \\
\hline & Human settlements & Arthrinium sp., Delitschia sp., Endophragmia sp., Valsaria sp. \\
\hline \multicolumn{2}{|c|}{ Algae (freshwater) } & Botryococcus sp., Pseudoschizaea sp., Zygnema sp. \\
\hline \multirow{5}{*}{ Phytoliths } & Bulliform & leaf \\
\hline & Culm & stem \\
\hline & Elongate echinate & inflorescence \\
\hline & Cross & leaf \\
\hline & Bilobate & leaf \\
\hline
\end{tabular}

reached $1 \mathrm{~m}$ in width when the trench was extended. It protruded into the sterile layer; it is almost u-shaped, and gives the impression it was a storage pit (Fig. 2). Layer D is yellowish brown (mottled yellowish brown in several areas), gritty and sandy; its thickness is in the range of $5 \mathrm{~cm}$ to $25 \mathrm{~cm}$. Layer E lies directly below layer D but is within layer F, the sterile layer. It is semi-compact with a concentration of ferric-oxide which is an indication of oxidation. It is about $17 \mathrm{~cm}$ thick, and occurs only in the northern wall. Layer F is mainly red in colour, wet and sticky clay; it also contained mottled yellowish brown "patches" in few areas, and is the sterile layer. It is mainly $20-25 \mathrm{~cm}$ thick. Layer G 

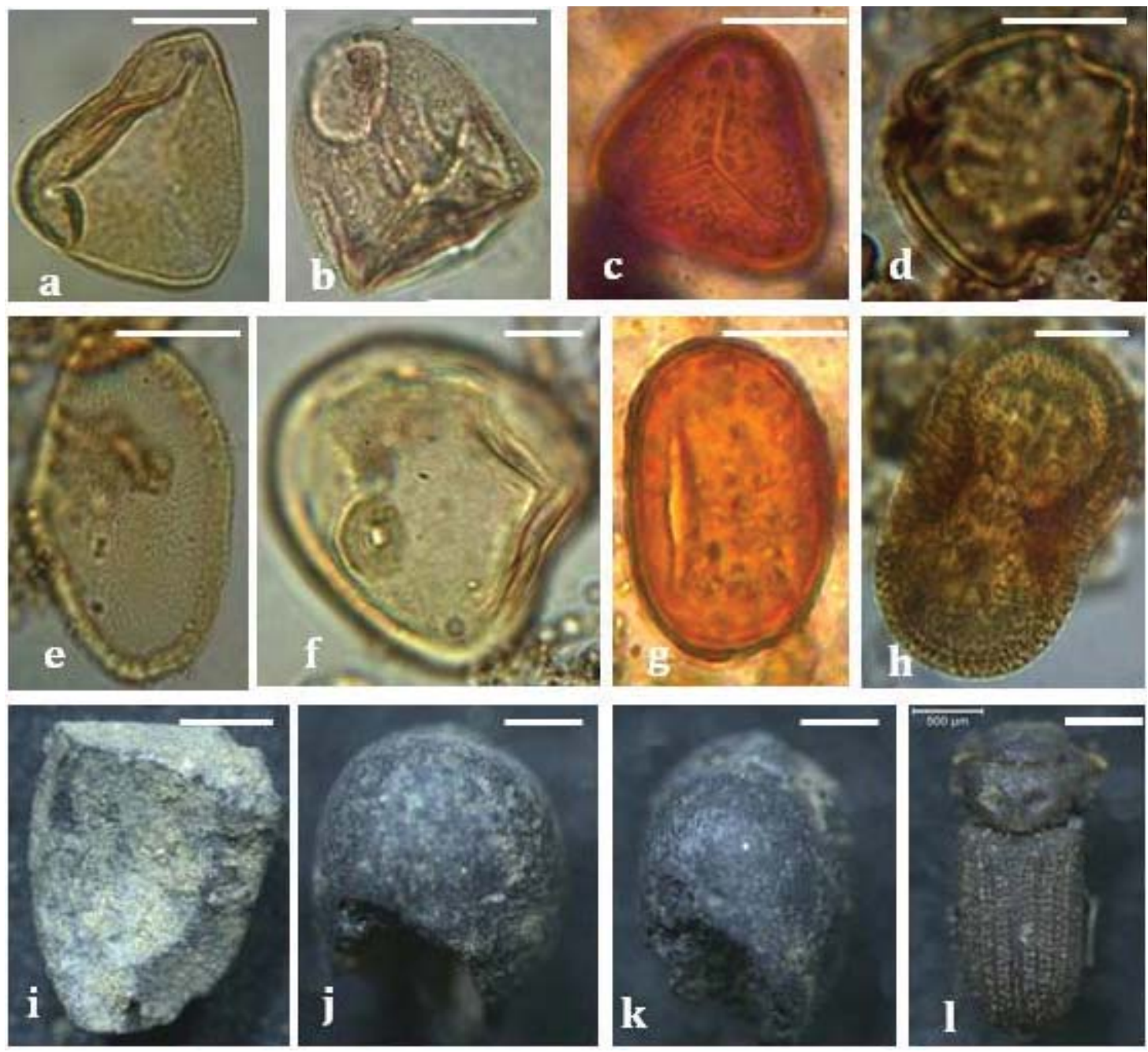

Fig. 3. Pollen, spores, seeds and beetle recovered from the archaeological sequence of B1 Tse Dura rock shelter 1 a-f: pollen grains; g: pteridophyte spore; i-k. seeds; 1. beetle a. Elaeis guineensis, b. Cyperaceae, c. Pteridium sp., d. Sarcocephalus latifolius (syn. Nauclea latifolia), e. Dioscorea sp., f. Poaceae, g. Monolete spore, h. Justicia sp., i. cf. Canarium schweinfurthii, j-k. Pennisetum glaucum, 1. cf. Palorus subdepressus

occurs as lens in two areas of the eastern wall; it is directly below layer $\mathrm{B}$ adjacent to $\mathrm{C}$, and above $\mathrm{C} 2$. Both are $c a .15$ $\mathrm{cm}$ thick; the soils therein are a mixture of red and black inclusions. With regard to the palaeoclimatic inference based on wet and dry taxa, the former group consisted of riverine forest, freshwater (aquatics) and aquatic algae, while the latter consisted of Guinea savanna and montane forest taxa.

\section{Palynology}

One hundred and forty-nine palynomorph types were recognised. Of this number, eighty-nine $(59.7 \%)$ were pollen grains, forty-three $(28.9 \%)$ were fungal spores, nine $(6 \%)$ were pteridophyte spores, five $(3.4 \%)$ were phytoliths and three $(2 \%)$ were algae types. Four pollen zones I, II, III and IV were identified based on changes in the pollen assemblage and lithology of the sediments. All the pollen zones but that of pollen zone II had two sub-zones each. They are as follows: TD B1 1a $(100-110 \mathrm{~cm})$, TD B1 $1 \mathrm{~b}$
(85-100 cm), TD B1 $2(70-85 \mathrm{~cm})$, TD B1 3a $(60-70 \mathrm{~cm})$; TD B1 3b $(45-60 \mathrm{~cm})$ and TD B1 $4 \mathrm{a}(30-45 \mathrm{~cm})$ and TD B1 $4 \mathrm{~b}(20-30 \mathrm{~cm})$. Pollen sum (pollen and pteridophyte spores) recovered from duplicate slides ranged from 190 to 685; pollen concentration ranged from 4,290/g to $13,700 / \mathrm{g}$. The photographs of some pollen, pteridophyte spore, seeds and beetle (cf. Palorus subdepressus) are shown in Fig. 3; the pollen diagrams are shown in Figs 4-5 while Fig. 6 shows a reconstruction of the palaeoclimate of the area in the last one millennium.

\section{POLLEN ZONES (TSE DURA B1)}

\section{Pollen Zone TD B1 1a (100-110 cm)}

At the beginning of the zone, Guinea savanna (35\%) was the most dominant vegetation type. Other taxa that were present included those of secondary forest, cultivars (Dioscorea spp.) and montane forests which were $8.7 \%$ 
each; herbaceous plants, aquatics, dry forests and Poaceae were $4.3 \%$ each. Trilete spores $(1.5 \%)$ occurred briefly but disappeared afterwards. Subsequently, secondary forest (38.3-40.3\%) became the most dominant taxa while Guinea savanna (17.7-13.6\%) and dry forests (4.3-3.2\%) both decreased; Cultivars (8.7-8.1\%) fluctuated but montane forest disappeared. Aquatics (13.6-1.6\%) decreased while Poaceae $(18.2-4.6 \%)$ which had an initial increase later decreased at the end of the zone. Fungal spores associated with erosion and fire such Chaetomium sp., Venturia sp., Valsaria sp., Cercophora sp. and Alternaria cf. tenuissima dominated; bulliform phytoliths (Poaceae) were also abundant.

\section{Pollen Zone TD B1 1 b $(85-100 \mathrm{~cm})$}

Secondary forest species (40-40.3\%) were the most dominant taxa; they were followed by those of Guinea savanna (11.7-17.7\%), Poaceae (13.3-17.7\%) and dry forests (3.2-9.4\%). Cultivars (8.1-5.9\%), aquatics (7.4-11.6\%) and herbaceous taxa $(2.9-4.8 \%)$ were also well represented. Combretaceae/ Melastomataceae species (1.1-2.9\%) which exhibited similar pattern as those of dry forests, and riverine forest species (5.9-8.3\%) occurred for the first time. At the end of the zone, secondary forest (40-20\%) though quite abundant experienced some decrease; in contrast, Guinea savanna elements (20-30\%) became dominant; herbaceous plants $(2.9-8.3 \%)$ and aquatics (4.6-11.6\%) increased; cultivars (5.9-5.0\%) fluctuated, while dry and montane forests disappeared. Fungal spores such as Chaetomium sp., Venturia sp. and Alternaria cf. tenuissima as well as bulliform phytoliths (Poaceae) decreased markedly while Valsaria and Cercophora fluctuated; in contrast, Delitschia, Brachydesmiella and fungal spore baculate were dominant. Other spores namely Fusarium, Curvularia and Aspergilus cf. flavus were present.

\section{Pollen Zone TD B1 2 (70-85 cm)}

Secondary forest elements (20-37.2\%) were quite abundant they later decreased $(19.2-10.7 \%)$ and the end of the zone. Conversely, Guinea savanna taxa which decreased at the beginning (30-16.6\%) increased (19.2-24.8\%) at the end of the zone. Poaceae (13-19.2\%), cultivars (5-13.7\%) and herbaceous plants (10.2-12.2\%) were well represented. Riverine forests $(8.3 \%)$ and aquatics $(9.6 \%)$ which had good representation later decreased to $4.6 \%$ and $4.5 \%$ respectively at the end of the zone. During the same period, Combretaceae/ Melastomataceae were 3.8\% while dry $(1.3-7.6 \%)$ and montane forests $(1.5-3.8 \%)$ represented by Podocarpus milanjianus reoccurred at $80 \mathrm{~cm}$. The major fungal spores included fungal spore baculate, fungal spore long. Others include Chaetomium and Valsaria, Brachydesmiella, Cercophora, cf. Endophragmiella and cultigens commensals (Alternaria cf. tenuissima Fusarium, Curvularia and Aspergilus cf. flavus); bilobate phytoliths (Panicoideae) also occurred at $80 \mathrm{~cm}$.

\section{Pollen Zone TD B1 3a $(60-70 \mathrm{~cm})$}

Guinea savanna (24.8-36.8\%), Secondary forest (10.7$25.6 \%)$ and herbaceous elements $(9.6-12.2 \%)$ were the most dominant. The herbaceous plant Alternanthera repens occurred for the first time at $60 \mathrm{~cm}$. Poaceae $(15.3-9.6 \%)$ and cultivars (13.7-7.2\%) fluctuated; aquatics (4.5-2.3\%) and riverine forest $(4.6-2.9 \%)$ species were also present. Dry forest $(7.6-21.2 \%)$ and montane forest $(1.5-8.0 \%)$ species had an increase at $65 \mathrm{~cm}$ but later decreased to $2.4 \%$ and $0 \%$ respectively. Fungal spore long, and fungal spore baculate decreased while Valsaria and Delitschia increased; Chaetomium and Brachydesmiella, Cercophora and Endophragmiella occurred. The cultigens commensals were also present; Diporotheca occurred for the first time. Bulliform phytolith (Poaceae) re-occurred.

\section{Pollen Zone TD B1 3b (45-60 cm)}

Guinea savanna (24-36.8\%) and Poaceae (9.6-32.1\%) were the most dominant taxa encountered but secondary forest elements decreased (25.6-12.0\%); aquatics (2.4-3.2\%), dry forest (2.4-16.6\%), Combretaceae/ Melastomataceae $(1.2-1.6 \%)$ were well represented. In contrast, riverine $(1.2 \%)$ and montane forests $(5 \%)$ had low occurrences. At the end of the zone, dry forest (16.6-5.0\%) and Poaceae (32.1-13.3\%) decreased but Guinea savanna (18.5-48.3\%) and herbaceous taxa (1.2-6.0\%) dominated. Among the herbaceous elements was Celosia cf. argentea which, along with monolete ferns occurred for the first time; both monolete $(8-14.8 \%)$ and trilete spores $(7.4 \%)$ were represented. Fungal spore long, fungal spore baculate, Chaetomium and Arthrinium were the dominant fungal spores; Delitschia decreased slightly but Valsaria had significant decrease. Coniochaeta cf. ligniaria occurred for the first time. Of the cultigens fungal spores, only Aspergillus cf. flavus occurred. Bulliform phytoliths decreased while elongate echinate and culm (cone-shaped) phytoliths were present.

\section{Pollen Zone TD B1 4a (30-45 cm)}

There was an abundance of secondary forest species (17.4-23.1\%) while Guinea savanna (15.9-14.3\%) and Poaceae (26.1-14.3\%) experienced fluctuations. Aquatics (6.4-21.4\%) became well represented at the end of the zone; cultivars (4.6-12.7\%) and herbaceous plants (3.1$7.1 \%$ ) were also present; Asystasia gangetica occurred for the first time at $35 \mathrm{~cm}$ accompanied by new set of fungal spores. Dry forest $(6.1-4.7 \%)$ and Combretaceae/ Melastomataceae (30-1.6\%) decreased; monoletes decreased $(6.3-0 \%)$ while triletes increased (1.6-14.6\%). Riverine and montane forests disappeared. Chaetomium, Aspergillus cf. clavus and Coniochaeta cf. ligniaria were the dominant fungal spores; bulliform phytoliths were also well represented. 


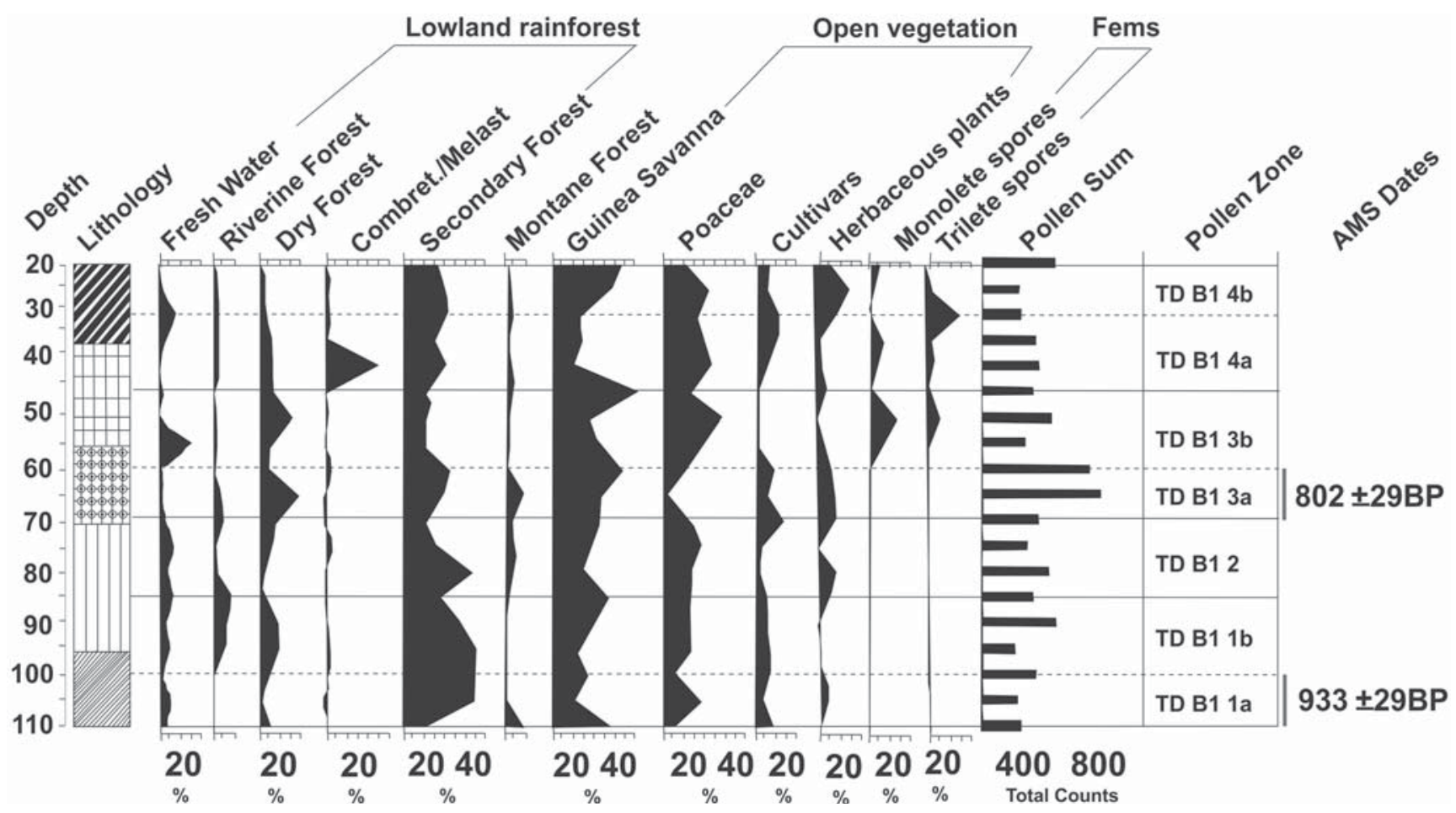

Fig. 4. Pollen diagram of KA4 Tse Dura rock shelter showing pollen and pteridophyte spores.

\section{Pollen Zone TD B1 4b (20-30 cm)}

Guinea savanna (15-38.4\%) had a significant increase; secondary forests elements (17.4-24.4\%) were also well represented. However, Poaceae (23.4-11.6\%), herbaceous plants $(19.8-6.9 \%)$ and cultivars $(11.3-5.8 \%)$ experienced some decrease. Similarly, aquatics $(21.4-1.2 \%)$ and trilete spores (14.3-1.2) had very significant decrease; monoletes were present $(2.1-4.6 \%)$. Dry forests $(6.1-1.2 \%)$ and Combretaceae/ Melastomataceae (2.7-1.2\%) were very much reduced. Coniochaeta $\mathrm{cf}$. ligniaria remained the most dominant fungal spore; phytoliths were scanty.

\section{DISCUSSION}

\section{Pollen Zone TD B1 1 (933 $\pm 29 \mathrm{BP}$ - prior to $802 \pm 29 \mathrm{BP})$}

The environment during the period, this part of the rock shelter was occupied was dated to $933 \pm 29 \mathrm{BP}$ (cal AD 1161). The environment was characterised by Guinea savanna and grasses (Fig. 4); it is likely that dry conditions prevailed. The soils are clayey and compact; they are red in colour and contain micaceous inclusions (Table 1). Although the soils are red in colour which indicated oxidation potentials (Eyre, 2013), pollen and spores were fairly well preserved. The lithology is in support of the inferred drier conditions. This is further reflected in the moderate values of secondary forest elements, as well as low values of aquatics and dry forests. In addition, the occurrence of montane taxa (Myrica arborea) is indicative of cool conditions. In the region of Lake Chad, the basin of which covers northern Nigeria, Niger, Chad, Algeria, Libya and Sudan, dust arising from very arid climate experienced marked increase at 1,000 BP (Cockerton et al., 2014). Similarly, after 2,000 BP water levels of Lake Chad dropped to $175 \mathrm{~m}$ below Mid Holocene levels (Armitage et al., 2015) which reflected the very arid conditions which prevailed during that period in the Sahara region. Arid conditions occurred in Lake Tilla ca. 3,800 BP; by 1,000 BP conditions had deteriorated owing to human intervention (Salzmann, 2000); Lake Tilla is ca. $450 \mathrm{~km}$ to the north of Tse Dura, and is in the Sudan-Sahel savanna zone in Northern Nigeria. Similar climatic and vegetation changes were recognised to have begun from $c a$. 1,470 \pm 79 in Nsukka with evidence of some anthropogenic influence (Njokuocha and Akaegbobi, 2014); Nsukka is located in the Derived savanna, and approximately $170 \mathrm{~km}$ west of Tse Dura. In addition, the inferred dry climate seems contemporaneous with those from Kariya Wuro (ca. 1,000 BP) to the north (Sowunmi and Awosina, 1991; Switsur et al., 1994), and of the coastal areas (Lac Sélé) in Southern Bènin which take place around 1,000-1,100 BP (Salzmann and Hoelzmann, 2005) and around 1,190 $\pm 30 \mathrm{BP}$ in Ogudu near Lagos, Nigeria (Orijemie, 2013).

However, despite the prevalence of dry conditions, secondary forest was also an important part of the environment because it subsequently became dominant which 


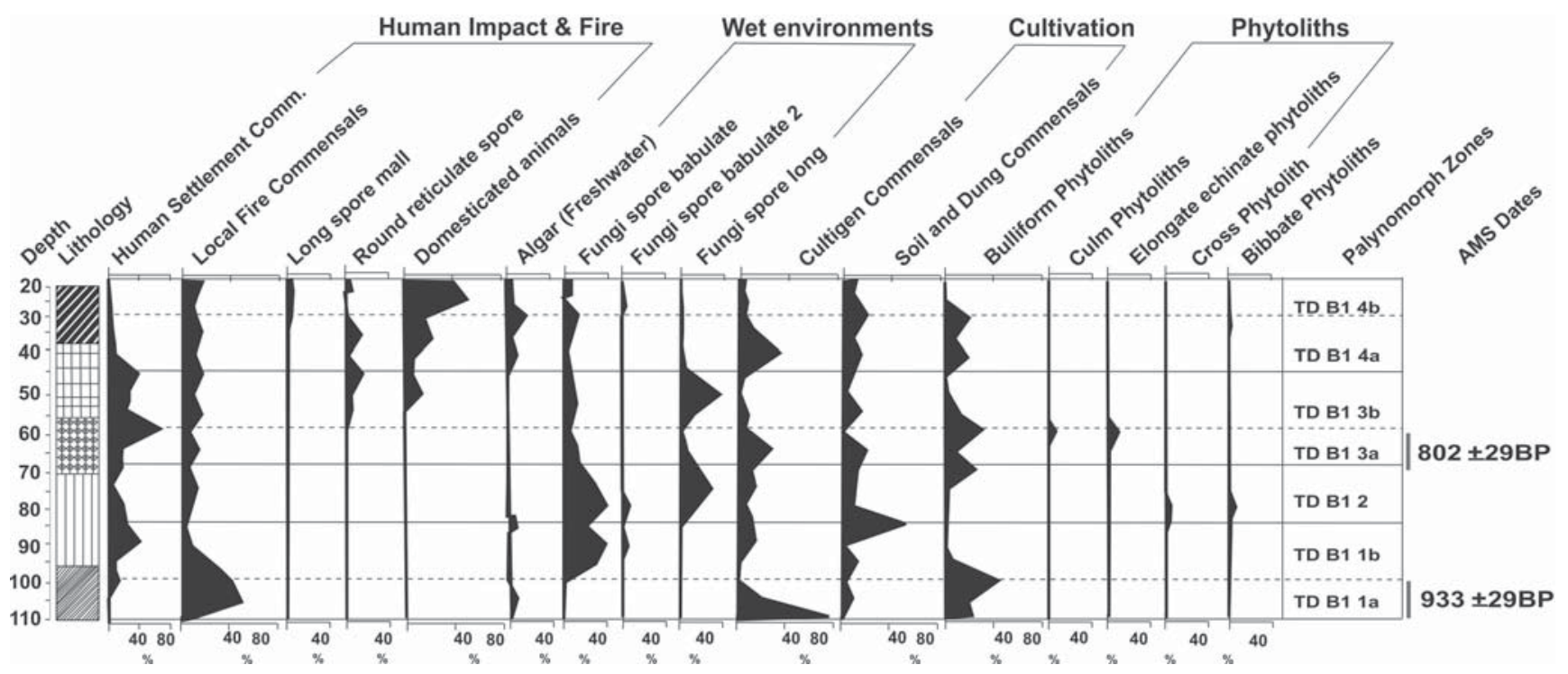

Fig. 5. Diagram of KA4 Tse Dura rock shelter showing fungal spores, algae and phytoliths.

seems to indicate a prevalence of humid and warm conditions. This is corroborated by the concomitant marginal decrease in Guinea savanna and disappearance of montane forest elements. Furthermore, the increase in aquatics, marginal increase in forests and appearance of riverine forests and ferns (represented by trilete spores) are in support of the inferred humid and warm climate. At the end of the zone, both Guinea savanna and secondary forest became the most abundant vegetation types in the landscape, an indication that the environment was open and probably drier than the previous times. Subsequently, the appreciable increase in riverine forest species and aquatics (freshwater) indicated that humid conditions persisted and were probably restricted to river banks and swamps. Human impact on the environment was quite prominent owing to the rise in herbaceous taxa (Amaranthaceae/ Chenopodiaceae and Asteraceae), the parent plants of which are usually found in anthropogenically disturbed places. Similarly, the fungi recovered were those associated with fire (Chaetomium sp. and Venturia sp.), human settlements (Valsaria sp.), soil and dung (Cercophora sp.) and cultigens (Alternaria cf. tenuissima) (Fig. 5). The subsequent increase in Delitschia and Valsaria indicated intensification of human impact on the landscape. In addition, intensified cultivation of plants (yams and pearl millet) is revealed by a diversification of the cultigens commensals (Fusarium, Curvularia and Aspergilus cf. flavus).

It is instructive that the occurrence of secondary forest taxa and cultivars, which were dominated by Elaeis guineensis (oil palm) and Dioscorea spp. (yams) respectively, indicated the importance of these food plants as part of the culture of the inhabitants of the rock shelter. The oil palm is one of the most important economic trees in West Africa and has been exploited since ca. 9,000 BP - Present (Oas et al., 2015; Sowunmi, 1981; Sowunmi and Awosina,
1991; Alabi, 2000). Hitherto, the exploitation of yams had been known only from linguistic evidence (Williamson, 1987, 1993). The recovery of its pollen indicated its possible exploitation. Although it is difficult to differentiate the pollen of cultivated Dioscorea from those of wild forms, the occurrence of beetle cf. Palorus subdepressus, one of the major pests of stored yams (Korada et al., 2010), suggests that the yams may not have been wild forms. The increase noted in the Poaceae and occurrence of bulliform phytoliths indicated the exploitation of grasses, among which was Pennisetum glaucum (pearl millet), the charred caryopses (1.5-2 $\mathrm{mm}$ in size) of which were also recovered (Fig. 3). The other plants which were exploited included those of Amaranthaceae/ Chenopodiaceae, some of which are consumed as leafy vegetables (Alyegba et al., 2013) and Cyperaceae (Cyperus cf. esculentus), the ripe fruits of which are eaten.

Three plants, the pollen of which were also recovered in substantial amount, and which are of ethnobotanical importance in northern Nigeria are Pavetta crassipes, Sarcocephalus latifolius (syn. Nauclea latifolia) and Lophira cf. lanceolata (Aliyu et al., 2008). The fruits of Pavetta and Sarcocephalus latifolius are known to have been exploited by LSA populations in Kariya Wuro, to the north of Tse Dura (Sowunmi and Awosina, 1991). Among the Tiv, the stems of Pavetta crassipes (Ato a ikpan) and Sarcocephalus latifolius (syn. Nauclea latifolia) (Ikurakase) are used in the treatment of internal wounds and jaundice (Awai and Igoli, 2015). Burkill (1985) stated that the leaves and roots of Pavetta crassipes are used in producing arrow-poisons, while Aliyu et al., (2008) recognised it for respiratory and related problems. P. crassipes seems to be a wonder plant as the ethnopharmacological importance has been well recognised (Amosa et al., 1998). On the other hand, both stems and roots of Lophira cf. lan- 
ceolata (Ikuranomso) are used in aborting foetuses (Awai and Igoli, 2015). These indicate that the human population at Tse Dura engaged in the management of oil palm, yams (tubers), pearl millet (Pennisetum glaucum), grasses and vegetables as well as the exploitation of wild trees and shrubs for dietary and ethnomedicinal purposes.

\section{Pollen Zone TD B1 2 (Just before $802 \pm 29$ BP)}

During the early phase of this period, the environment was basically secondary forest vegetation although Guinea savanna taxa occurred (Fig. 4); also present were riverine forests and aquatic species (freshwater) indicating humid climatic conditions. The pollen evidence revealed a change from an environment characterised by Guinea savanna with dry and cool conditions to a humid and warm one. Subsequently, there were marked increases in Guinea savanna elements, Poaceae and montane forests (Justicia flava, Ilex mitis and Podocarpus milanjianus) along with concomitant decrease in species indicative of wet conditions such as riverine forests and aquatics.

The re-occurrence of montane forests and dry forest type towards the end of the zone revealed the existence of cooler and drier conditions. However, the notable increase in Poaceae, cultivars and herbaceous plants in substantial amounts indicated a landscape that was still under strong anthropogenic influence. Continued human occupation of the rock shelter is depicted not only in the cultural artefacts but also in the diversification of fungi (Fig. 5) particularly those associated with human settlements (Valsaria) and human-related activities (Brachydesmiella, Cercophora, cf. Endophragmiella), as well as local fire and erosion (Chaetomium). The exploitation of Pennisetum glaucum, Dioscorea spp., Elaeis guineensis, Pavetta cf. crassipes, Sarcocephalus latifolius (Syn. Nauclea latifolia) and Cyperaceae, as major plant foods continued. The occurrence of cross and bilobate phytoliths which are produced in the leaves of Panicoideae grasses (Barboni et al., 2007) suggest that Panicoideae grasses (to which Pennisetum glaucum belongs) were harvested and brought into the rock shelter for processing. The recovery of the caryopses of pearl millet continued throughout the trench until they disappeared after $20 \mathrm{~cm}$. In addition, the occurrence of cultigens commensals (Alternaria cf. tenuissima Fusarium, Curvularia and Aspergilus cf. flavus) appears to be in support of local presence of pearl millets. Furthermore, the occurrence of Prosopis africana pollen is significant; $P$. africana is called Gbaaye among the Tiv, and its seeds are used as a local condiment (Alyegba et al., 2013).

The vegetation changes were accompanied by some cultural changes. First, there was significant increase in pottery from 43 in the previous period to 149 (Table 3); this phenomenon may be reflective of an increased need to process higher number and types of foods, as well as growing human population. Second, there was an occurrence of pottery decoration types hitherto unrecovered. They constituted $4.7 \%$ of the total body sherds, and are namely twisted mat impression, burnished and twisted cord roulette. Vessels with these decoration types are currently known among the Tiv people. Vessels with twisted mat impression are used mainly for processing pearl millet and sorghum into malt (Lo), non-alcoholic (Bier) and alcoholic (Tashi) drinks. On the other hand, vessels with burnished and twisted cord roulette decorations called Tsuwa are used for three different purposes namely serving soup, preparing herbal medicines and for cooking. The burnished effect is produced from the Kpine tree (Bridelia ferruginea), a tradition that continues till date in Tivland. The third change was an increase in microliths (side scrapers, backed blade and tanged piece), chips, chunks and flakes, and hammer stones (Table 3) as well as the occurrence of a tooth of Thryonomys swinderianus (greater cane rat/grasscutter). The diversification of lithics and occurrence of animal tooth indicated increased hunting activities.

\section{Pollen Zone TD B1 3 (802 \pm 29 BP - just before $310 \pm 30$ BP)}

The dominance of Guinea savanna, secondary forest and herbaceous elements during the early period of this level indicated a continued occurrence of environmental conditions as was in the previous level (Fig. 4). The colour of the sediments was not significantly different from that of the previous level but they became semi-compact, clayey and fine in texture. These lithological features are characteristic of improved climatic conditions. Notable increases in Poaceae and cultivars revealed probable intensification of human impact. At the end of the zone, Guinea savanna, Poaceae, secondary forests and dry forests still remained the most dominant, an indication the landscape was still open. In addition, spores of ferns were recovered for the first time; some of them (Pteris sp.) are naturally found in moist environments and along freshwater swamps. The recovered fungi indicated the continued impact of humans on the environment. Diporotheca is linked with an almost treeless landscape (van Geel et al., 2011), which was open or grassy environment as depicted in re-occurrence of bulliform phytoliths (Fig. 5). The subsequent decrease in fungi associated with humans (Valsaria and Delitschia) coincided with the first occurrence of Coniochaeta cf. ligniaria; C. cf. ligniaria is associated with herbivores hence might indicate a possible introduction of herbivores. In addition, the recovery of elongate echinate and culm phytoliths which are produced in the inflorescence and stems of grasses (Poaceae) indicated an increased use of grasses (cultivated and wild forms).

Among the herbaceous plants, Alternanthera cf. repens occurs for the first time. Alternanthera repens is a weedy species associated with anthropogenic disturbances; its occurrence supports a stronger impact of humans on the landscape. However, the increase in dry and montane forests was unexpected, and may be associated with some form of human action which enabled forest trees to regenerate (Fig. 4). Three significant cultural changes occurred during 
this period namely (i) an initial and marked reduction in pottery from 149 in the previous level to $48(60 \mathrm{~cm})$ at the beginning of the level (Table 3); (ii) first occurrence of ground-stone axe concomitant with increases in herbaceous plants (Celosia cf. argentea) and (iii) significant increase in lithics and iron slags. The initial reduction in pottery suggests that there is the likelihood that some form of migration took place which seems to be supported by marked reduction in the fungi spores associated with human settlements (Valsaria and Delitschia) and the concomitant increase in forest species albeit of the drier type. The recovery of ground-stone axe, and appearance of new pottery technique (embossed) and decorations (carved wood roulette) are significant because they were accompanied by vegetation changes one of which was the occurrence of Celosia sp.; Celosia is a leafy vegetable consumed in the study area.

\section{Pollen Zone TD B1 4 (just before $310 \pm 30$ BP - Present)}

The dominance of secondary forest species and cultivars indicated a more significant impact on the vegetation by humans. Environmental conditions at the beginning of this period appeared to have been warm and humid with the occurrence of light brown-brown sandy soils, good representation of aquatics as well as concomitant fluctuations in Guinea savanna and Poaceae, and disappearance of montane forest elements (Fig. 4). In addition, the appearance of Asystasia gangetica, a weed of disturbed places is significant. It is almost intolerant of shade and can often be found in alluvium soils of river banks; Its occurrence was accompanied by increases in the fungal spores namely Coniochaeta cf. ligniaria, Canalisporium sp. and Chaetomium sp. Coniochaeta cf. ligniaria is indicative of high density of domesticated animals (van Geel et al., 2011); Chaetomium sp. and Canalisporium are associated with forest clearance, fire and erosion (Argant et al., 2006).

At $30 \mathrm{~cm}$, there was an unprecedented increase in aquatics $(21.4 \%)$ and fungal spores $(30.8 \%)$; this was an indication that wet conditions prevailed during that period. Although the sediments from the layer were not dated, it seems contemporaneous with the lowest level $(55 \mathrm{~cm})$ of a sediment core drilled in the freshwater swamp of the Katsina Ala River. The Tse Dura hill is approximately 25 km away from the Katsina Ala River; however, a tributary of the Katsina Ala, River Amire Tamen flows near the Tse Dura hill complex. It is therefore not farfetched to infer that sediments of the Katsina Ala floodplains were partly derived from the hills; this phenomenon partly accounts for the similarities in the lithology of both sediments. The Tse Dura sediments (at $30 \mathrm{~cm}$ ) are dark grey in colour, a bit loose and sandy; those of the sediment core (at $55 \mathrm{~cm}$ ) were dark grey in colour, loose and sandy. The other similarity derives from patterns in the pollen and spore assemblages. The sediment core $(55 \mathrm{~cm})$ was dominated by an abundance of aquatic and freshwater species (12.6-28\%) such as Cyperaceae, Ludwigia and Typha while fungal spores $(35.7 \%)$ were also comparable to those from the rock shel- ter. In contrast Guinea savanna elements $(0-2.9 \%)$ had very low occurrence. This level, inferred to have been wet, was dated to cal. AD 1485-1650. However, the most significant occurrence among the fungi was Coniochaeta cf. ligniaria, which are associated with the presence of herbivores (van Geel et al., 2011). Accompanying these vegetation changes were cultural changes. The high amount of archaeological artefacts indicated that this level was the most diversified period in terms of human occupation at the site. Subsequently, it was also during this period that caryopses of cf. Sorghum bicolor were recovered. The environment became more open with the dominance of Guinea savanna and Poaceae. This was followed by drastic reduction in aquatics, triletes and dry forest species.

\section{PALAEOCLIMATIC RECONSTRUCTION}

A comparison of the wet and dry taxa recovered from the Tse Dura rock shelter site is represented in Fig. 6. From the diagram, periods of major and minor climatic variability were revealed; the major variability included wet and warm, or dry and cool periods while the minor variability was a wet-dry transition period. From 110-95 cm, there were fluctuations in climate such that the environment alternated between dry and wet conditions with dry conditions occurring at $110 \mathrm{~cm}$ and wet at $105 \mathrm{~cm}$. Hence a cyclic pattern of climatic events was established such that a dry and cool period was succeeded by a wet and warm phase and it succeeded by a transitional wet-dry phase. The earliest dry event occurred around $933 \pm 29$ BP (cal AD 1161), and agrees with Tubosun, (1981, 1995) who indicated that dry and cool environmental phase occurred just after 1,100 BP. This dry event appears to be the "relict" of the Late Holocene Dry Phase which began in north-eastern Nigeria around ca. 3,800 BP (Salzmann, 2000), and northern parts of Bauchi at ca. 1000 BP (Sowunmi and Awosina, 1991). Cockerton et al., (2014)

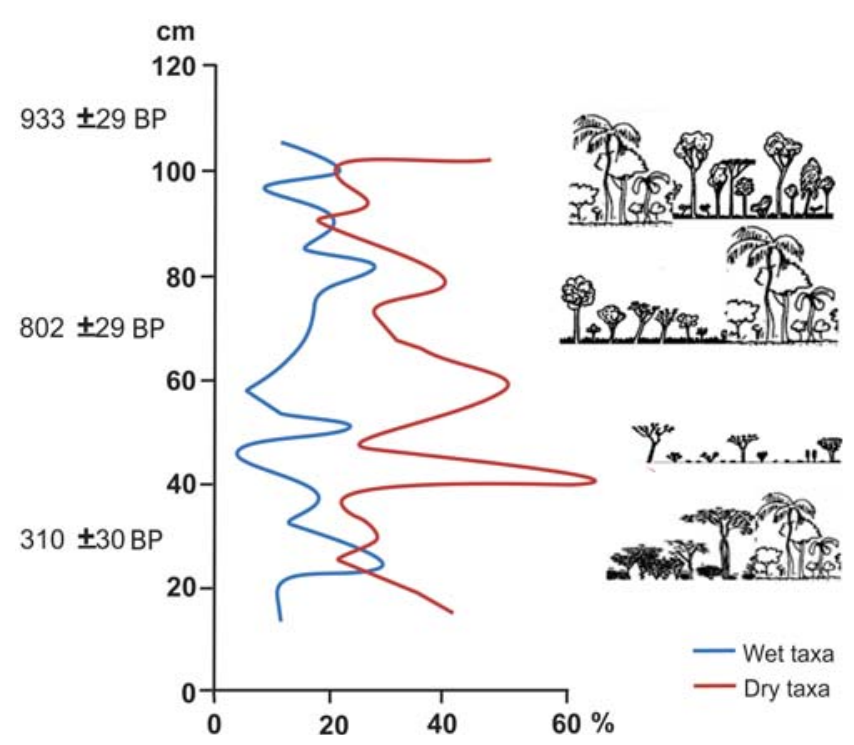

Fig. 6. Reconstructed palaeoclimate at Tse Dura based on a comparison between wet and dry taxa. 
stated that the environment in the northernmost parts of Nigeria during this period was influenced by human activities but did not provide the drivers of this inferred human impact. The recovery of several figurines of animals (mostly large herbivores such as sheep, goat and cattle) in the Daima area of north-eastern Nigeria dating to the 1st-2nd millennium AD (Connah, 1981) alludes to grazing activities which would have had devastating effects on the already marginal landscape. In contrast, there seems to be no evidence of adverse effects of human-induced climate change at Tse Dura during this period. However, the occurrence of "new" pottery types (finger impressed and embossed pottery) in the archaeological record indicated migration of populations from northern Nigeria and Cameroon into the Middle Benue Valley. Finger impressed pottery occurred in NE Nigeria ca. 1,200 BP (Connah, 1981) and Dumbu site in the Gongola area around $810 \pm 80$ BP (Van Noten and De Ploey 1977); embossed pottery was recovered from Shum Laka rock shelter (Cameroon) from ca. 2500-900 BP (de Maret, 2013; Lavachery, 1996). The impact these migrations would have had on the indigenous populations (hunter-gatherers) is not clear. The fact that the dominant pottery type, the knitted mat impressed pottery, was not displaced suggested that some form of cultural assimilation rather than acculturation might have occurred.

Subsequently, a transition phase between wet and dry climate occurred during the period when level 90-80 cm was deposited. A second period of dry and cool condition occurred at $80-60 \mathrm{~cm}$; it was during this period that cultivars (5-13.7\%), dominated by Dioscorea spp., increased which was an indication that human impact on the vegetation was significant. In addition, pottery with wavy and/ or circular lines appeared in substantial amount. Pottery with wavy lines has been associated with food producing communities of 7000-5000 BP in the Sudan (MohammedAli and Khabir, 2003) but this Sudan Neolithic culture does not seem to have reached Tse Dura rather Iron Age (900-1000 BP) populations in Cameroon with similar pottery (Lavachery, 1996) may have migrated into the Middle Benue Valley and impacted Tse Dura. This dry and cool event which came to an end around $802 \pm 29 \mathrm{BP}$ (cal AD 1274) appeared to have lasted for a considerable length of time, and was succeeded by a wet and warm phase. Another major dry phase occurred afterwards, and this is probably contemporaneous with the Little Ice Age (LIA), a period which is believed to have commenced at $c a$. AD 1400 (Russell and Johnson, 2007). Another wet phase is inferred to have occurred at cal. AD 1485-1650, and it was succeeded by a transitional wet-dry phase. This phenomenon altered the cycle of climatic events which had begun since $c a$. 1,000 yr BP. The reconstructed vegetation during that time was dominated by grasses $(22.2 \%)$, secondary forests $(17.1 \%)$ and cultivars and herbaceous plants (15.9\%).

It is likely that among the Poaceae pollen was Sorghum bicolor. It was during this period that the grains of Sorghum bicolor (Guinea corn) appeared in the archaeobotanical records. Sorghum bicolor, in comparison to Pennisetum glaucum requires higher amount of water hence its occur- rence may be a cultural response by the people to the inferred wet phase. This data clearly indicated strong human impact on the environment, and their activities may have contributed significantly to the climate change beginning from that period. In fact, the several flooding events and prolonged dry seasons noted in the middle Benue Valley landscape particularly settlements located around the Rivers Makurdi and Katsina Ala areas might not be unconnected to anthropogenic impact. It appears quite interesting that the fairly high amount of riverine forest elements in periods inferred to have been dry indicated that the inhabitants adopted the strategy of exploiting these plants. They would have been collected from swamps and wetlands along the Katsina Ala River and its tributaries and brought back to the rock shelter. Conversely, during periods inferred to have been wet, the lack of any major change in the riverine forests indicates they may not have constituted the best and most rewarding areas from where plants would have been actively sourced.

\section{CONCLUSION}

A reconstruction of the vegetation history of Tse Dura, a Later Stone Age archaeological site in north-central Nigeria, using pollen and spores was carried out. The reconstruction revealed that the site experienced alternating vegetation changes almost throughout. These changes were also accompanied by cultural changes. The first period began ca. $933 \pm 29$ BP (cal AD 1161), was initially dominated by Guinea savanna and characterised by dry conditions although secondary forest existed. Managed plants (Dioscorea spp. and Pennisetum glaucum), Elaeis guineensis and wild species (Pavetta crassipes, Sarcocephalus latifolius and Lophira cf. lanceolata) were exploited. The inhabitants also engaged in the production of pottery, iron and microliths, the latter were used in hunting game. There were favourable conditions shortly after $802 \pm 29$ BP (cal $A D$ 1274). Riverine and drier forests flourished; however, human impact on the environment was most significant. Humid conditions continued until AD 1485-1650 when the environment became very wet after which it was succeeded by a drier period until it reached its current status.

\section{Acknowledgements}

The research project was funded by a Newton International Fellowship 2016-2017; additional funding was received from the McDonald Institute for Archaeological Research, University of Cambridge D M McDonald Grants and Award 2016\& 2017. Special thanks go to the Tiv families for their hospitality at Ushongo.

\section{REFERENCES}

Alabi, R.A., 2000. Apa: A Later Stone Age occupation layer in the Southwestern Coast of Nigeria. Nyame Akuma 53, 29-34. Alabi, R.A., 2016. Down through memory lane: history of human oc- 
cupation of the rainforest belt of southwestern Nigeria from the Late Pleistocene to the Holocene. In: Oyelaran, P.A., Alabi, R.A., Adeonipekun, P.A. (Eds), Human Palaeoecology in Africa: essays in honour of Prof M. Adebisi Sowunmi. Ibadan University Press, Ibadan, 238-282.

Alabi, R.A., Aleru, J.O., Opadeji, A.O., Usman, A., 2009. A HunterGatherer Community in the Rain Forest Belt of Southwestern Nigeria. Nyame Akuma 72, 74-77.

Aliyu, A.B., Musa, A.M., Oshanimi, J.A., Ibrahim, H.A., Oyewale, A.O., 2008. Phytochemical analysis and mineral elements composition of some medicinal plants of Northern Nigeria. Nigerian Journal of Pharmaceutical Sciences 7, 1, 119-125.

Allsworth-Jones, P., 2015. Kariya Wuro: A Late Stone Age Site in Northern Nigeria, Africa Magna Verlag, Frankfurt-am-Main.

Allsworth-Jones, P., Oyelaran, P.A., Stringer, C., Compton, T., 2012. Itaakpa, a Late Stone Age site in southwestern Nigeria. Journal of Field Archaeology 37, 3, 163-177.

Alyegba, S.S, Roy, M and Dagba, Ioryem, B., 2013. Ethnobotanical Survey of Edible Wild Plants in Tiv Communities of Benue State, Nigeria. Journal of Natural Sciences Research 3, 7, 17-23.

Amosa, S., Okwuasabab, F.K., Gamaniela, K., Akaha, P., Wambebea, C., 1998. Inhibitory effects of the aqueous extract of Pavetta crassipes leaves on gastrointestinal and uterine smooth muscle preparations isolated from rabbits, guinea pigs and rats. Journal of Ethnopharmacology 61, 3: 209-213.

Andah, B.W., 1983. The Bantu Homeland Project: Ethnoarchaeological investigations in parts of the Benue Valley Region. West African Journal of Archaeology 13, 23-60.

Argant, J., López-Sáez, J.A., Bintz, P., 2006. Exploring the ancient occupation of a high altitude site (Lake Lauzon, France): Comparison between pollen and non-pollen palynomorphs. Review of Palaeobotany and Palynology 141, 1, 2, 151-163.

Armitage, S.J., Bristow, C.S., Drake, N.N., 2015. West African monsoon dynamics inferred from abrupt fluctuations of Lake MegaChad. Proceedings of the National Academy of Sciences 112, 28, 8543-8548.

Awai, E.P., Igoli, J.O., 2015. Medicinal Plants used in Antenatal and Perinatal Care among the Tiv People of Benue State, Nigeria. Indo Global Journal of Pharmaceutical Sciences 5, 1, 90-93.

Barboni, D., Bremond, L., Bonnefille, R., 2007. Comparative study of modern phytolith assemblages from inter-tropical Africa. Palaeogeography, Palaeoclimatology, Palaeoecology 246, 454- 470.

Burkill, H.M., 1985. The useful plants of West Tropical Africa (Vol. 4). Royal Botanic Gardens, Kew, United Kingdom.

Cockerton, H.E., Holmes, J.A., Street-Perrott, F.A., Ficken, K.J., 2014. Holocene dust records from the West African Sahel and their implications for changes in climate and land surface conditions. Journal of Geophysical Research: Atmospheres 119, 8684-8694.

Connah, G., 1981. Three Thousand years in Africa: Man, and his environment in the Lake Chad region of Nigeria. Cambridge University Press, Cambridge.

de Maret, P., 2013. Archaeologies of the Bantu Expansion. In: Mitchell, P., Lane, P. (Eds), The Oxford Handbook of African Archaeology. Oxford University Press, Oxford, 627-644.

Eyre, S.R., 2013. Vegetation and Soils. A World Picture (Second Edition). Aldine Transaction, London.

Faegri, K., Iversen, J., 1988. Textbook of Pollen Analysis, John Wiley and Sons Alden Press London.

Fatunsin, F.K., 1996. Ifetedo: A Late Stone Age Site in the Forest Region of Southwestern Nigeria. West African Journal of Archaeology 26, 1, 71-87.

Hutchinson, J., Dalziel, J.M., 1958-1972. Flora of West Tropical Africa Vols I, II and III. Crown Agents for Oversea Governments and Administrations, Millbank, London, S.W. 1.

Keay, R.W.J., 1959. An Outline of Nigerian Vegetation. Federal Government of Nigeria, Lagos, Nigeria.
Korada, R.R., Naskar, S.K, Edison, S., 2010. Insect pests and their management in yam production and storage: a world review. International Journal of Pest Management, 56, 4, 337-349.

Lavachery, P., 1996. Shum Laka rock shelter Late Holocene deposits: from stone to metal (North Western Cameroon). In: Gilbert, P., Soper, R. (Eds), Aspects of African Archaeology. Papers from the $10^{\text {th }}$ Congress of the PanAfrican Association for Prehistory and Related Studies. University of Zimbabwe Publications, Harare, 265-274.

Mohammed-Ali, A.S., Khabir, A., 2003. The wavy line and dotted wavy line pottery in the prehistory of the Central Nile and SaharaSahel Belt. African Archaeological Review 20, 91, 25-58.

Njokuocha, R., Akaegbobi, I. M., 2014. A contribution to the Holocene vegetation history of Nigeria: Pollen from Ohe Pond Nsukka, southeastern Nigeria. Quaternary International 338, 28-34.

Oas, S. E., D’Andrea, A.C., Watson, D.J., 2015. 10,000 year history of plant use at Bosumpra Cave, Ghana. Vegetation History and Archaeobotany 24, 635-653.

Orijemie, E.A., 2013. A Palynological and Archaeological Investigation of the Environment and Human occupation of the Rainforest of South-Western Nigeria during the Late Holocene Period. An Unpublished PhD Thesis, University of Ibadan, Nigeria.

Orijemie, E.A., in press. Late Holocene Archaeobotanical evidence for Pearl millet (Pennisetum glaucum) in the Tse Dura Rock shelter 1, north-central Nigeria.

Orijemie, E.A., Aleru, J.O., Opadeji, O.A., Ajekigbe, P.G., in press. AB1: A Late Stone Age Rock Shelter in the Rainforest of Nigeria.

Oyelaran, P.A., 2002. Vegetation Change in the Pollen Assemblage of Osaru Pond. Environmental Issues 24, 32-37.

Reimer, P.J., Bard, E., Bayliss, A., Beck, J.W., Blackwell, P.G., Bronk, R.C., Buck, C.E, Cheng, H., Edwards, R.L., Freidrich, M., Grootes, P.M., Guilderson, T.P., Haflidason, H., Hajdas, I., Hatte, C., Heaton, T.J., Hoffmann, D.G., Hogg, A.G., Hughen, K.A., Kaiser, K.F., Kromer, B., Manning, S.W., Nui, M., Reimer, R.W., Richards, D.A., Scott, E.M., Southon, J.R., Staff, R.A., Turney, C.S.M., van der Plicht, J., 2013. 'IntCal13 and Marine13 Calibration Curves 0-50,000 Years BP'. Radiocarbon 55, 4, 1869-1887.

Russell, J.M., Johnson, T.C., 2007. Little Ice Age drought in equatorial Africa: Intertropical Convergence Zone migrations and El Niño Southern Oscillation variability. Geology 35, 1, 21-24.

Salzmann, U., 2000. Are modern savanna degraded forests? - A Holocene pollen record from the Sudanian vegetation zone of NE Nigeria. Vegetation History and Archaeobotany 9, 1-15.

Salzmann, U., Hoelzmann, P., 2005. The Dahomey Gap: an abrupt climatically induced rain forest fragmentation in West Africa during the late Holocene. The Holocene 15, 190-199.

Shaw, T., Daniels, S.G.H., 1984. Excavations at Iwo-Eleru. West African Journal of Archaeology 14, 1-269.

Soper, R.C., 1965. The Stone Age in Northern Nigeria. Journal of the Historical Society of Nigeria 3, 175-194.

Sowunmi, M.A., 1981. Late Quaternary Environmental Changes in Nigeria. Pollen et Spores 23, 1, 125-148.

Sowunmi M.A., Awosina, E.O., 1991. Pollen analyses of Kariya Wuro Rock Shelter, Bauchi State. The Nigerian Field 56, 163-170.

Switsur, R., Otto, T., Allsworth-Jones, P., 1994. New dating evidence and wood identification of wood charcoal from Kariya Wuro Rock shelter, Bauchi State. The Nigerian Field 59, 135-145.

Tubosun, B.J., 1981. Geo-Archaeology: Tse-Dura Prehistoric Rock shelters (Benue State of Nigeria) as a case study. Unpublished M.Sc. Dissertation, Department of Archaeology, University of Ibadan, Nigeria.

Tubosun, B.J., 1995. Geo-Archaeological Investigations in Adikpo area of Katsina-Ala River basin, Benue State, Nigeria. Unpublished Ph.D. Thesis, Department of Archaeology and Anthropology, University of Ibadan.

Tubosun, B., Andah, B.W., 1983. Sedimentological Analysis of 
Tse-Dura Prehistoric Rock shelter Deposits. West African Journal of Archaeology 13, 61-72.

van Geel, B., Gelorini, V., Lyaruu, A., Aptroot, A., Rucina, S., Marchant, R., Sinninghe Damsté, J.S., Verschuren, D., 2011. Diversity and ecology of tropical African fungal spores from a 25,000-year palaeoenvironmental record in southeastern Kenya. Review of Palaeobotany and Palynology 164, 174-190.

Van Noten, F., De Ploey, J., 1977. Quaternary Research in NorthEastern Nigeria. Musee Royal De L'Afrique Centrale-tervuren, Belgique Annales Serie $\mathrm{IN}-8^{\circ}$-Sciences Humaines $\mathrm{n}^{\circ} 92$.

Williamson, K., 1987. Linguistic evidence for the prehistory of the Ni- ger Delta. In: Alagoa, E.J., Anozie, F.N., and Nzewunwa, N. (Eds), The Early History of the Niger Delta. Sprache und Geschichte in Afrika SUGIA - Beiheft 8. Herausgegeben an den Universitaten Koln und Bayreuth, 65-119.

Williamson, K., 1993. Linguistic evidence for the use of some tree and tuber food plants in southern Nigeria. In: Shaw, T., Sinclair, P., Andah, B, Okpoko, A., (Eds), The Archaeology of Africa. Food, Metals and Towns. Routledge, London and New York, 139-153.

York, R.N., 1978. Excavations at Dutsen Kongba, Plateau State, Nigeria. West African Journal of Archaeology 8, 139-163. 